OPEN ACCESS

Edited by:

David Rodriguez-Lazaro, University of Burgos, Spain

Reviewed by: Alessandra De Cesare, Università di Bologna, Italy Beatrix Stessl, Veterinärmedizinische Universität Wien, Austria

*Correspondence: Changyun Ye yechangyun@icdc.cn

Specialty section: This article was submitted to

Food Microbiology, a section of the journal Frontiers in Microbiology

Received: 08 January 2018 Accepted: 07 May 2018 Published: 29 May 2018

Citation: Li H, Wang P, Lan R, Luo L, Cao X, Wang Y, Wang Y, Li H, Zhang L, Ji S and Ye C (2018) Risk Factors and Level of Listeria monocytogenes Contamination of Raw Pork in Retail Markets in China.

Front. Microbiol. 9:1090. doi: 10.3389/fmicb.2018.01090

\section{Risk Factors and Level of Listeria monocytogenes Contamination of Raw Pork in Retail Markets in China}

\author{
Hua Li'1,2, Pengfei Wang', Ruiting Lan ${ }^{3}$, Lijuan Luo', Xiaolong Cao ${ }^{1,4}$, Yi Wang ${ }^{1}$, \\ Yan Wang ${ }^{1}$, Hui Li ${ }^{1{ }^{15}}$, Lu Zhang ${ }^{1}$, Shunshi ${ }^{1}{ }^{1}$ and Changyun Ye ${ }^{1 *}$
}

\begin{abstract}
' State Key Laboratory of Infectious Disease Prevention and Control, Collaborative Innovation Center for Diagnosis and Treatment of Infectious Diseases, National Institute for Communicable Disease Control and Prevention, Chinese Center for Disease Control and Prevention, Beijing, China, ${ }^{2}$ Tongzhou District Center for Disease Control and Prevention, Beijing, China, ${ }^{3}$ School of Biotechnology and Biomolecular Sciences, University of New South Wales, Sydney, NSW, Australia, ${ }^{4}$ Beijing Changping Institute for Tuberculosis Prevention and Treatment, Beijing, China, ${ }^{5}$ Department of Microbiology, Guizhou Medical University, Guiyang, China
\end{abstract}

Listeria monocytogenes can contaminate various foods via food processing environments and contamination of raw materials. There is a limited understanding of $L$. monocytogenes transmission in retail market and the role of insects in L. monocytogenes transmission in the retail environments. To better understand the risk factors of raw pork contamination, the prevalence of $L$. monocytogenes was examined in raw pork, retail environments and insects in a retail market over a 6-month period from March to August in 2016 in Beijing, China. A total of 2,789 samples were collected, including 356 raw pork samples, 1,392 meat contact surface swabs (MCS), 712 nonmeat contact surface swabs (NMCS) and 329 insect samples. Overall, 424 (15.20\%) of the samples were found to be contaminated by L. monocytogenes. Analyzed by serotyping, multilocus sequence typing and pulsed-field gel electrophoresis, the 424 L. monocytogenes isolates were divided into three serotypes (1/2c, 1/2a and 3a), 15 pulsotypes (PTs) and nine sequence types (STs), 1/2c/PT4/ST9 (244/424, 58\%) was the most prevalent type of $L$. monocytogenes strains. The raw pork, MCS of the environments and insects were contaminated with higher levels of $L$. monocytogenes than NMCS of the environments, which suggested that cross contamination of L. monocytogenes between raw pork and the environment existed in the retail market, and long-term contaminated surfaces and vector insects would act as high risk factors to transmit $L$. monocytogenes to raw pork. Thus more effective strategies are needed to reduce the risk of retail pork meat contamination by $L$. monocytogenes and prevent foodborne human listeriosis.

Keywords: Listeria monocytogenes, retail market, environment, insects, cross contamination

\section{INTRODUCTION}

Listeria monocytogenes is a food-borne pathogen that causes severe infections in humans (Zhou et al., 2010; Galvao et al., 2012; Pagliano et al., 2017; Lowe et al., 2018), especially the elderly, pregnant women, newborns and immunocompromised individuals (Fleming et al., 1985; Gilmour et al., 2010; Lamont et al., 2011). The diseases caused by L. monocytogenes include meningitis, 
sepsis, gastroenteritis, neonatal infections and fetal loss (Lamont et al., 2011; Pagliano et al., 2017; Lowe et al., 2018). A total of 256 cases of listeriosis were reported from 1964 to 2013 in China, involved 48 perinatal women, 86 neonatal and 122 non-perinatal women and more sporadic cases of listeriosis were reported in recent years (Wu et al., 2008; Zhou et al., 2010; Sun et al., 2016). Listeriosis outbreaks have been reported in many countries including Japan, the United States and Europe (European Food Safety Authority, 2011; Miya et al., 2015; Self et al., 2016). Human infections caused by L. monocytogenes have become a global health concern.

Listeria monocytogenes is ubiquitous in the environment (Wagner and Stessl, 2014; Conficoni et al., 2016). It can adhere to many surfaces and form biofilms, and has the ability to survive and grow at low temperatures, a wide range of $\mathrm{pH}$, high salt concentrations and low water activity (Duffy and Sheridan, 1997; Miettinen et al., 1999a,b; Freitag et al., 2009). L. monocytogenes has been isolated from various food products, including raw and cooked meats, milk products, seafood and vegetables (Ballesteros et al., 2011; Jami et al., 2014; Moosavy et al., 2014; Brown et al., 2016; Luo et al., 2017). High levels of L. monocytogenes contamination in raw pork in China have been reported (Zhang et al., 2007, 2013; Yang et al., 2008; Huo et al., 2015). In addition, L. monocytogenes can persist in foodprocessing environments causing recurrent contamination of final products (Nucera et al., 2010; O'Connor et al., 2010; Galvao et al., 2012). The bacterium enters the processing plant generally through raw materials, drainers, aerosols, personnel movements and food-processing facilities. In addition, a wide variety of ready-to-eat food, retail food and related environments have been found to be contaminated by L. monocytogenes in Canada, Italy, China and the United States in recent years (Hoelzer et al., 2011; Kovacevic et al., 2012; Simmons et al., 2014; Wu et al., 2015; Conficoni et al., 2016).

Currently, the understanding of risk factors of L. monocytogenes contamination of raw meat in retail market is limited, especially in China. A recent study showed that the retail environment played an important role in L. monocytogenes contamination in pork retail markets, but few environmental samples were collected (Luo et al., 2017). Insects such as flies and cockroaches can carry pathogens (Barreiro et al., 2013), but little is known about their role in L. monocytogenes transmission in China. Thus, we conducted this survey of L. monocytogenes contamination in raw pork, environments and insects in a raw pork retail market, and serotyping, multilocus sequence typing and pulsed-field gel electrophoresis were used to determine the characteristics of L. monocytogenes isolates and evaluate their potential risk to foodborne human listeriosis.

\section{MATERIALS AND METHODS}

\section{Sample Collection}

Samples from the retail environments and raw pork were collected from 65 booths (which distributed in four rows) monthly for 6 months (March 2016-August 2016) in a raw pork retail market located in Beijing, China. The average temperature between March 2016 and August 2016 were 12, 20, 26, 30, 31 , and $30^{\circ} \mathrm{C}$ respectively. A total of 2,789 samples were collected, including 356 raw pork samples, 2,104 raw pork retail environment swabs (1,392 MCS swabs from chopping boards and knives, the inner and outer surfaces of chest freezers, meat mincers, hands of persons, and 712 NMCS swabs from floors and walls), and 329 insects (185 flies and 144 cockroaches) samples. Environmental samples were collected using sterile swabs, rehydrated before use with $5 \mathrm{ml}$ of sodium chloride solution (0.9) in sterile tubes. The sampling surface areas were $100-900 \mathrm{~cm}^{2}$ and samples were collected before cleaning and disinfection. Additionally, approximately $25 \mathrm{~g}$ of fresh raw pork sample contacting with chopping boards were collected in sterile bags. Most fresh raw pork in the retail market was sold within the day and any unsold meat were stored at $-20^{\circ} \mathrm{C}$ in the freezer (each booth equipped one chest freezer for storage). Every 20 flies or cockroaches were pooled together to increase the sensitivity of isolation (Olsen and Hammack, 2000; Holt et al., 2007; Forster et al., 2009). All samples were maintained at $4^{\circ} \mathrm{C}$ for transport and storage, and were detected within $24 \mathrm{~h}$.

\section{Isolation of $L$. monocytogenes}

Isolation of L. monocytogenes was performed in accordance with ISO11290-1 (1996) method with partial modifications. Samples were examined with two steps of enrichment. Solid samples (pork pieces, $25 \mathrm{~g}$ ) mixed with $225 \mathrm{ml}$ Half Fraser broth and each environmental swab was mixed with $10 \mathrm{ml}$ Half Fraser (Oxoid Ltd., Hampshire, United Kingdom) and were then incubated for $24 \mathrm{~h}$ at $30^{\circ} \mathrm{C}$ with shaking $(220 \mathrm{rpm})$. Subsequently $1 \mathrm{ml}$ of the above culture was transferred into $9 \mathrm{ml}$ Fraser (Oxoid Ltd.) for $48 \mathrm{~h}$ at $37^{\circ} \mathrm{C}$ with shaking $(220 \mathrm{rpm})$. Flies and cockroach samples were pulverized before culturing because that L. monocytogenes could exist on the body surface as well as the alimentary canal of a single fly (Pava-Ripoll et al., 2015). Enriched broth was then spread onto brilliance listeria agar (Oxoid Ltd.) for 24-36 h at $37^{\circ} \mathrm{C}$. Presumptive L. monocytogenes colonies (3-5) were purified in brain heart infusion (BHI) agar (Landbridge Ltd., Beijing, China) for another $24 \mathrm{~h}$ at $37^{\circ} \mathrm{C}$. For DNA extraction, pure strains from BHIA were transferred into $200 \mu$ l Tris-EDTA (TE) buffer, vibrating, blending and boiling the mixture at $100^{\circ} \mathrm{C}$ for 10-15 $\mathrm{min}$, and then centrifuged for $3 \mathrm{~min}$ (13000 r/min), the supernatant was stored at $-20^{\circ} \mathrm{C}$. PCR amplification of Listeria genus and species of the isolates was determined by specific primers (Ryu et al., 2013).

\section{Serotyping of $L$. monocytogenes Isolates}

Multiplex PCR serogrouping was carried out according to the method of Doumith et al. (2004). Subsequently, specific serotypes were determined by combining with the conventional Denka Seiken serotyping (Burall et al., 2011).

\section{Pulsed-Field Gel Electrophoresis (PFGE) Typing Based on Ascl Digestion}

Pulsed-field gel electrophoresis (PFGE) was performed according to the Pulse-Net standardized protocol for L. monocytogenes 
using AscI (Graves and Swaminathan, 2001; Sauders et al., 2003; Wang et al., 2012). Salmonella enterica serovar Braenderup strain $\mathrm{H} 9812$ restricted with XbaI was used for molecular weight determinations in all PFGE gels. The PFGE patterns were analyzed by using BioNumerics Software version 7.0 (Applied Maths, Saint-Martine, Belgium) and setting Dice coefficient and position tolerance at $1.0 \%$ for band comparison, and the pattern profiles were grouped together according to the unweighted pair group method with arithmetic average (UPGMA). The pulsotypes were standardized and compared with those in the database of PulseNet China.

\section{Multilocus Sequence Typing (MLST)}

Multilocus sequence typing was performed based on sequence analysis of seven housekeeping genes ( $a b c Z, b g l A, c a t, d a p E$, dat, $l d h, \operatorname{lh} k A)$. Lasergene's Seqman software was used to compare the sequence. Analysis of allelic profiles or sequence types of the L. monocytogenes strain was done on the website ${ }^{1}$. Minimum spanning tree was created by BioNumerics Software version 7.0 (Applied Maths, Saint-Martine, Belgium).

\section{Statistical Analysis}

To analyze the statistical significance $(p<0.05)$ of differences in the prevalence of L. monocytogenes in different booths, months and sample categories, chi square $\left(\mathrm{X}^{2}\right)$ test and Fisher exact test were performed using SAS (version 9.4, SAS Institute Inc.).

\section{RESULTS}

\section{Prevalence of $L$. monocytogenes in Different Samples}

A total of 2,789 samples were collected and 424 (15\%) samples were positive for L. monocytogenes. L. monocytogenes isolation rate was 29, 16, 4, and $20 \%$ for raw pork, MCS, NMCS and insects samples respectively. The difference of positive rates among different sample types (raw pork, MCS, NMCS and insects) were significant $\left(\chi^{2}=130.972, P<0.0001\right)$. Among MCS samples, contamination of chopping boards and knives (25\%) was higher than that of outer surfaces of chest freezers (14\%) and meat mincers (13\%). The rates among 10 sample types in Table 1 were statistically significant $\left(\chi^{2}=160.418, P<0.01\right)$. The contamination rates of raw pork and MCS (excluding chopping board and knives, and meat mincers) varied significantly among different sampling months. The monthly contamination rate ranged from 14 to $22 \%$, and incidences in May (22\%), June (20\%) and July (19\%) were higher than the average rate of $15 \%$, indicating that the months with higher contamination rate of L. monocytogenes was also the months with higher temperature (Table 1).

${ }^{1}$ http://bigsdb.pasteur.fr/perl/bigsdb/bigsdb.pl?db=pubmlst_listeria_seqdef_ public

\section{Serotypes and Genotypic Characterizations of $L$. monocytogenes Isolates}

Total of $424 \mathrm{~L}$. monocytogenes isolates were divided into three serotypes: $1 / 2 \mathrm{c}(73 \%), 1 / 2 \mathrm{a}(15 \%)$ and $3 \mathrm{a}(12 \%)$. Serotype $1 / 2 \mathrm{c}$ isolates was predominant in all sample types including raw pork, MCS, NMCS and insects (Table 1). All L. monocytogenes isolates belonged to 15 pulsotypes (PTs), and PT4 was the most prevalent pulsotype (58\%), followed by PT279 (10\%), PT16 (8\%), PT11 (6\%) and PT54 (8\%) (Figure 1). The predominant PT4 counted for $60,59,68$, and $45 \%$ isolates of raw pork, MCS, NMCS and insects respectively (Table 1). Nine sequence types (STs) were found, and the most common STs were ST9 (72\%), followed by ST155 (12\%), ST121 (8\%) and ST8 (6\%). Furthermore, ST9 was the main ST isolated from raw pork, MCS, NMCS and insects, accounting for $72,77,89$, and $46 \%$ respectively (Table 1 ). A minimum spanning tree of the STs was constructed (Figure 2). Most of the STs differed by two or more alleles while ST35, ST120, and ST705 differed by one allele to ST9, ST8, and ST155 respectively (Figure 2). There was a good concordance for serotypes, pulsotypes and sequence types, the majority of ST9 isolates (80\%) belonged to PT4 while ST155 and ST121 isolates were predominantly inclusive of PT54 (64\%) and PT16 (100\%) respectively (Figure 1). The serotypes $1 / 2 \mathrm{a}, 1 / 2 \mathrm{c}$ and $3 \mathrm{a}$ isolates were mainly belonging to ST121 (56\%), ST9 (99\%) and ST155 (96\%) respectively.

In general, L. monocytogenes $1 / 2 \mathrm{c} / \mathrm{PT} 4 / \mathrm{ST} 9$ isolates were predominant $(244 / 424,58 \%)$, which recovered from samples of different sources (raw pork, MCS, NMCS, and insects), and accounted for $77,70,67,63,60,59,55,51,45$, and $44 \%$ of L. monocytogenes isolates obtained from meat mincers, walls, floors, chopping board and knives, raw pork, the outer surfaces of chest freezers, hands, the inner surfaces of chest freezers, cockroaches and flies respectively. Notably, as the second predominant isolates from insects, PT16 (32\%) strain presented at lower proportion of isolates from raw pork (2\%), MCS (6\%) and NMCS (0).

\section{High-Risk Booths and Repeated Contamination of $L$. monocytogenes}

Based on the number of L. monocytogenes isolates obtained from the 65 booths, the relative risk of $L$. monocytogenes contamination among the booths was assessed. There were eight types of samples including raw pork, inner and outer surfaces of chest freezers, meat mincers, hands, floors, walls, flies and cockroaches in each booth and there were a total of 48 samples per months obtained in each booth during the 6 months. The total number of L. monocytogenes isolates per booth varied from one to 16 with a median of six. The majority of the booths $(82 \%)$ were contaminated with one to nine L. monocytogenes. High-risk contamination booths were defined at the median level of six isolates or above and 37 booths (57\%) were classified as high-risk booths.

Listeria monocytogenes with the same pulsotype was repeatedly isolated from the same site (the same booth or the same sampling type) in different dates. Overall, 51 booths 
TABLE 1 | Prevalence, temporal distribution, phenotypic and genotypic characteristics of L. monocytogenes isolates collected from raw pork, environments and insects in retail market.

\begin{tabular}{|c|c|c|c|c|c|c|c|c|c|}
\hline \multirow[t]{2}{*}{ Sample category } & \multirow{2}{*}{$\begin{array}{l}\text { Sample } \\
\text { details }\end{array}$} & \multirow{2}{*}{$\begin{array}{c}\text { No. of } \\
\text { samples }\end{array}$} & \multirow{2}{*}{$\begin{array}{l}\text { No. }(\%) \text { of } \\
\text { isolates }\end{array}$} & \multicolumn{2}{|c|}{ Month variation } & \multirow{2}{*}{$\begin{array}{l}\text { High-risk } \\
\text { months }\end{array}$} & \multirow{2}{*}{$\begin{array}{c}\text { Serotypes } \\
\text { (No. of isolates) }\end{array}$} & \multirow{2}{*}{$\begin{array}{l}\text { STs (No. of } \\
\text { isolates) }\end{array}$} & \multirow{2}{*}{$\begin{array}{c}\text { PTs } \\
\text { (No. of isolates) }\end{array}$} \\
\hline & & & & $x^{2}$ & $P$ & & & & \\
\hline Meat $^{a}$ & Raw pork & 356 & $104(29)$ & 30 & $<0.0001$ & $\begin{array}{c}\text { April, } \\
\text { March, May }\end{array}$ & $\begin{array}{c}1 / 2 \mathrm{c}(75), \\
1 / 2 \mathrm{a}(15), 3 \mathrm{a}(14)\end{array}$ & $\begin{array}{c}9(75), 155(14), \\
8(11), 121(2), \\
307(2)\end{array}$ & $\begin{array}{c}4(62), 279(11), \\
11(11), 54(11) \\
44(2), 41(2) \\
16(2), 98(1) \\
224(1), 259(1)\end{array}$ \\
\hline \multirow[t]{5}{*}{$\begin{array}{l}\text { Meat contact } \\
\text { surfaces }\left(\mathrm{MCS}^{\mathrm{b}}\right)\end{array}$} & $\begin{array}{l}\text { Chopping } \\
\text { boards and } \\
\text { knives }\end{array}$ & 367 & $91(25)$ & 9.8 & 0.0796 & $\begin{array}{l}\text { April, July, } \\
\text { May, June }\end{array}$ & $\begin{array}{c}\text { 1/2c (72), } \\
1 / 2 \mathrm{a}(11), 3 \mathrm{a}(8)\end{array}$ & $\begin{array}{c}9(71), 155(8), \\
8(6), 121(4) \\
204(1), 307(1)\end{array}$ & $\begin{array}{c}4(57), 279(11), \\
11(6), 16(4), \\
44(4), 9(3), 54(2), \\
98(2), 41(1), 5(1)\end{array}$ \\
\hline & $\begin{array}{l}\text { Inner } \\
\text { surfaces of } \\
\text { freezers }\end{array}$ & 303 & $39(13)$ & 12.8 & 0.0254 & $\begin{array}{l}\text { July, } \\
\text { August }\end{array}$ & $\begin{array}{c}1 / 2 \mathrm{c}(29) \\
1 / 2 \mathrm{a}(5), 3 \mathrm{a}(5)\end{array}$ & $\begin{array}{c}9(29), 155(4) \\
8(3), 121(2) \\
705(1)\end{array}$ & $\begin{array}{c}4(20), 279(5), \\
54(5), 9(3), 11(3), \\
16(2), 270(1)\end{array}$ \\
\hline & $\begin{array}{l}\text { Outer } \\
\text { surfaces of } \\
\text { freezers }\end{array}$ & 310 & $44(14)$ & 13.0 & 0.0236 & July, May & $\begin{array}{c}1 / 2 c(33), 3 a(6), \\
1 / 2 a(5)\end{array}$ & $\begin{array}{c}9(32), 155(5), \\
121(4), 8(1) \\
204(1), 307(1)\end{array}$ & $\begin{array}{c}4(26), 16(4), \\
279(3), 54(3), \\
98(2), 9(2), 5(1), \\
11(1), 44(1), 73(1)\end{array}$ \\
\hline & $\begin{array}{l}\text { Meat } \\
\text { mincers }\end{array}$ & 100 & $13(13)$ & - & $0.0051^{e}$ & $\begin{array}{c}\text { June, May, } \\
\text { April }\end{array}$ & $1 / 2 c(13)$ & $9(13)$ & $4(10), 7(1)$ \\
\hline & Hands & 312 & $40(13)$ & 7.4 & 0.1946 & $\begin{array}{l}\text { July, May, } \\
\text { March }\end{array}$ & $\begin{array}{c}1 / 2 \mathrm{c}(30) \\
1 / 2 \mathrm{a}(5), 3 \mathrm{a}(5)\end{array}$ & $\begin{array}{c}9(30), 155(5) \\
121(3), 8(2)\end{array}$ & $\begin{array}{c}4(22), 9(4), 16(3), \\
279(3), 11(2), \\
44(2), 54(3), \\
224(1)\end{array}$ \\
\hline \multirow[t]{2}{*}{$\begin{array}{l}\text { Non-meat contact } \\
\text { surfaces }\left(\mathrm{MMCS}^{\mathrm{C}}\right)\end{array}$} & Floors & 358 & $18(5)$ & - & $0.0294^{f}$ & March, May & 1/2c (16), 1/2a (2) & $\begin{array}{c}9(16), 8(1) \\
120(1)\end{array}$ & $\begin{array}{c}4(12), 279(4) \\
11(2)\end{array}$ \\
\hline & Walls & 354 & $10(3)$ & - & $0.1467^{\mathrm{g}}$ & May, July & $1 / 2 c(9), 3 a(1)$ & $9(9), 155(1)$ & $4(7), 279(2), 44(1)$ \\
\hline \multirow[t]{2}{*}{ Insects ${ }^{d}$} & Flies & 185 & 34 (18) & 27.3 & $<0.0001$ & $\begin{array}{l}\text { July, } \\
\text { August }\end{array}$ & $\begin{array}{c}\text { 1/2a (16), } \\
1 / 2 \mathrm{c}(15), 3 \mathrm{a}(3)\end{array}$ & $\begin{array}{c}121(16), 9(15), \\
155(3)\end{array}$ & $\begin{array}{c}16(16), 4(15) \\
54(2), 44(1)\end{array}$ \\
\hline & Cockroaches & 144 & $31(22)$ & - & $0.0004^{h}$ & May & $\begin{array}{c}1 / 2 \mathrm{c}(16), \\
1 / 2 \mathrm{a}(5), 3 \mathrm{a}(10)\end{array}$ & $\begin{array}{c}9(15), 155(10), \\
121(5), 35(1)\end{array}$ & $\begin{array}{c}4(14), 54(7), \\
16(5), 44(3), 7(1), \\
224(1)\end{array}$ \\
\hline Total & - & 2789 & $424(15)$ & - & - & $\begin{array}{l}\text { July, March, } \\
\text { May }\end{array}$ & $\begin{array}{c}\text { 1/2c (308), } \\
1 / 2 \mathrm{a}(64), 3 \mathrm{a}(52)\end{array}$ & $\begin{array}{c}9(305), \\
155(50), \\
121(36), 8(24), \\
307(4), 204(2), \\
705(1), 35(1), \\
120(1)\end{array}$ & $\begin{array}{c}4(245), 279(41), \\
16(36), 54(33), \\
11(25), 44(14), \\
9(12), 98(5), \\
41(3), 224(3), \\
5(2), 7(2), 73(1), \\
259(1), 270(1)\end{array}$ \\
\hline
\end{tabular}

${ }^{a}$ Meat, raw pork. ${ }^{b}$ MCS, meat contact surfaces. ${ }^{c}$ NMCS, non-meat contact surfaces. ${ }^{d}$ Insects, flies and cockroaches. ${ }^{e, f, g, h}$ Fisher exact test was performed.

$(51 / 65,78 \%)$ were found to be contaminated repeatedly (Figure 3), among them only 4 booths were contaminated by a single pulsotype (PT4) strains and 40 booths were contaminated by two to four different pulsotype strains. PT4 isolates was predominant and counted for $60 \%$ of 51 repeatedly contaminated booths (Figure 3). Furthermore, L. monocytogenes isolates from different months presented similar distribution of pulsotypes, at least five pulsotypes in each month were found with PT4 predominated. The monthly isolation of L. monocytogenes varied from 33 to 72 and the highest prevalence appeared in May (Supplementary Figure S1).

The highest frequency of L. monocytogenes pulsotypes in raw pork, MCS and NMCS at each booth during the sampling period was shown in Figure 4. The majority of raw pork, MCS and NMCS were contaminated by $L$. monocytogenes PT4 strains.
Overall, there was a higher level of contamination in raw pork and MCS samples (29\% and 16\%) than NMCS samples (4\%) (Figure 4).

\section{DISCUSSION}

Listeria monocytogenes contamination in raw pork is an important food safety concern. In this study, we investigated L. monocytogenes contamination of raw pork, retail environment and insects in a retail market, and identified the potential risk factors.

In this study, the L. monocytogenes contamination rate in raw pork was 29\%, which is higher than that of previous reports in China and other countries such as Chile and Japan (6-21\%) (Inoue et al., 2000; Chen et al., 2015; Montero et al., 2015; 


\begin{tabular}{|c|c|c|c|c|c|c|}
\hline PFGE-Ascl & PFGE-Ascl & & & & & \\
\hline 品 & & Pulsotype & $\begin{array}{c}\text { Serotype } \\
\text { (No.of isolates) }\end{array}$ & $\begin{array}{c}\mathrm{ST}(\mathrm{s}) \\
\text { (No.of isolates) }\end{array}$ & $\begin{array}{c}\text { Source(s) } \\
\text { (No.of isolates) }\end{array}$ & $\begin{array}{l}\text { No. of } \\
\text { isolates }\end{array}$ \\
\hline & & GX6A16.CN0007 & $1 / 2 c(2)$ & $9(2)$ & $\operatorname{MCS}(1) I(1)$ & 2 \\
\hline ᄂ & & GX6A16.CN0009 & $1 / 2 c(12)$ & $9(12)$ & $\operatorname{MCS}(12)$ & 12 \\
\hline ᄂ & & GX6A16.CN0279 & $1 / 2 c(41)$ & $9(41)$ & $\operatorname{MCS}(24) \mathrm{M}(11) \operatorname{NMCS}(6)$ & 41 \\
\hline & & GX6A16.CN0004 & $1 / 2 c(245)$ & $9(245)$ & MCS(135) M(62) I (29) NMCS(19) & 245 \\
\hline & & GX6A16.CN0005 & $1 / 2 c(2)$ & $204(2)$ & $\operatorname{MCS}(2)$ & 2 \\
\hline & & GX6A16.CN0011 & $1 / 2 a(25)$ & $120(1) 8(24)$ & $\operatorname{MCS}(12) \mathrm{M}(11) \operatorname{NMCS}(2)$ & 25 \\
\hline & & GX6A16.CN0073 & $1 / 2 c(1)$ & $9(1)$ & $\operatorname{MCS}(1)$ & 1 \\
\hline & & GX6A16.CN0016 & $1 / 2 a(36)$ & $121(36)$ & I (21) MCS(13) M(2) & 36 \\
\hline & & GX6A16.CN0259 & $1 / 2 c(1)$ & $9(1)$ & $M(1)$ & 1 \\
\hline & & GX6A1.CN00044 & $3 a(14)$ & $155(14)$ & $\operatorname{MCS}(7) M(2) I(4) \operatorname{NMCS}(1)$ & 14 \\
\hline L & & GX6A16.CN0054 & $3 a(33)$ & $155(33)$ & $\operatorname{MCS}(13) I(9) M(11)$ & 33 \\
\hline\llcorner & & GX6A16.CN0098 & $3 a(5)$ & 155(4)307(1) & $\operatorname{MCS}(4) M(1)$ & 5 \\
\hline & & GX6A16.CN0041 & $1 / 2 a(3)$ & $307(3)$ & $M(2) \operatorname{MCS}(1)$ & 3 \\
\hline & & GX6A16.CN0224 & $1 / 2 c(3)$ & $9(2) 35(1)$ & $M C S(1) M(1) \mid(1)$ & 3 \\
\hline & & GX6A16.CN0270 & $1 / 2 c(1)$ & $9(1)$ & $\operatorname{MCS}(1)$ & 1 \\
\hline
\end{tabular}

FIGURE 1 | Dendrogram of pulsed-field gel electrophoresis (PFGE) patterns based on Ascl digestion of 424 L. monocytogenes isolates from raw pork and environments in retail market. The PFGE patterns (PTs), serotypes, sequence types (STs), sources and number of strains are shown at right (MCS, meat contact surface; NMCS, non-meat contact surface; I, insects; M, raw pork).
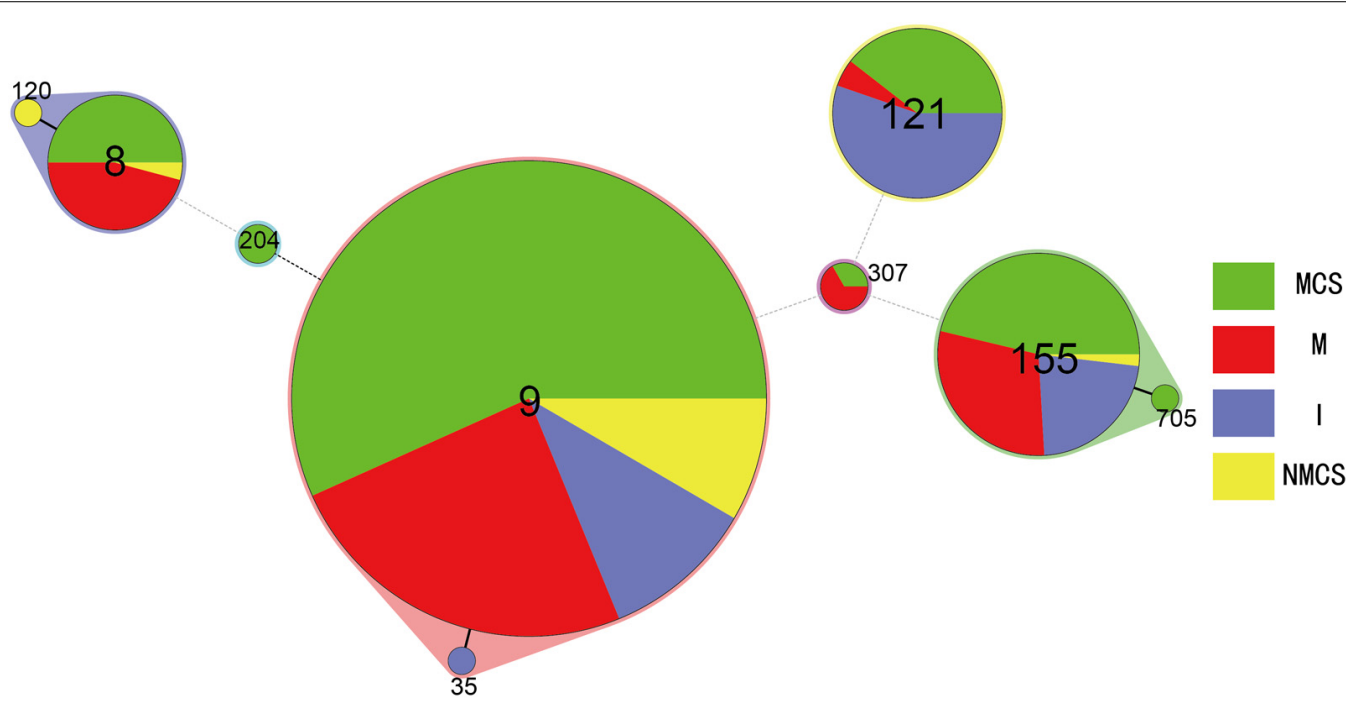

FIGURE 2 | Minimum spanning tree analysis of L. monocytogenes isolates from raw pork, environments and insects in retail market located in China. The data analyzed was based on MLST result of the isolates presented in Table 1. Circles correspond to sequence types (STs), the size of each circle is proportional to the number of isolates in each ST. The minimum spanning tree and the alignment were made using BioNumerics v7.0. (MCS, meat contact surface; NMCS, non-meat contact surface; I, insects; M, raw pork).

Wang K. et al., 2015; Wang W. et al., 2015; Luo et al., 2017). This higher rate of L. monocytogenes contamination in raw pork was more likely due to the contamination in the retail market rather than upstream of the processing or retail chain, because our previous study showed that L. monocytogenes contamination in slaughterhouses in Beijing was very low
(0.5\%) (Liu et al., 2014). Our another survey showed the level of L. monocytogenes contamination in the pork carcass swab samples from the wholesalers which supply raw pork to the retail market was lower with 10 of the 150 (7\%) tested samples being positive. and there was no L. monocytogenes isolated from the swab samples of the inner surfaces of meat 


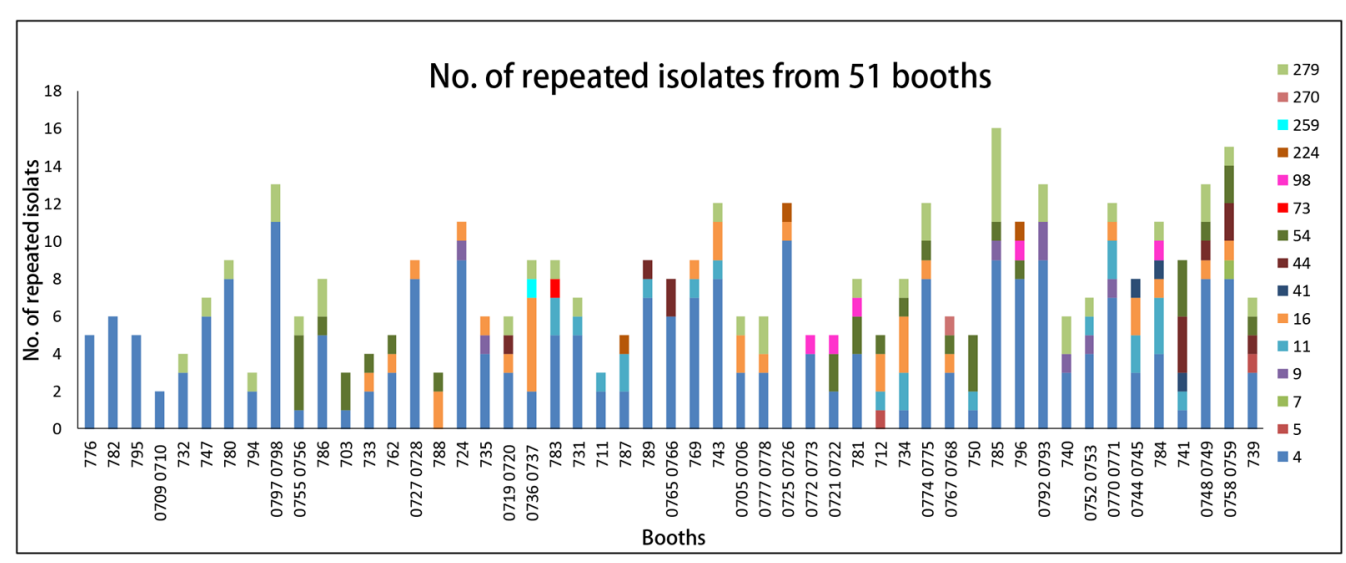

FIGURE 3 | The distribution of pulsotypes of $L$. monocytogenes isolates in 51 repeated contamination booths. X-axis, booth number. Y-axis, the number of repeated PTs isolates. Legend: different colors represent different pulsotypes of $L$. monocytogenes isolates.

trucks and motorized tricycles which were used for raw pork transporting in the first 3 months (unpublished data). Therefore, the main L. monocytogenes contamination source of raw pork possibly was not from slaughterhouse and transport links but likely from the retail market itself. MCS samples, especially chopping boards and knives were found to have a higher positive rate of L. monocytogenes than NMCS, which suggested that MCS would act as an important means to transmit L. monocytogenes to raw pork. The genotype similarity of the isolates also provided further evidence of transmission in this retail market. The predominant L. monocytogenes subtype strains (1/2c/PT4/ST9) isolated from environment (including MCS and NMCS) and insects were also the main subtype strains existed in raw pork. We also found that prevalence of L. monocytogenes was higher in months with higher temperature in our study, which was different from the patterns of report about that in southwest China (Luo et al., 2017), which possibly attributed to the difference of regional climate and retail environment.

As the report shows, most human cases of listeriosis were caused by serotype L. monocytogenes $1 / 2 \mathrm{a}, 1 / 2 \mathrm{~b}$ and $4 \mathrm{~b}$ strains (Pan et al., 2010), while serogroup 1/2a and 3a strains caused $47 \%$ of human clinical cases from 1958 to 2010 in Sweden (Lopezvalladares et al., 2014). L. monocytogenes strains of serotypes $(1 / 2 \mathrm{a}, 1 / 2 \mathrm{~b}, 1 / 2 \mathrm{c})$, pulsotype PT4, sequence types (ST9, ST8, ST87, ST3) were the predominant foodborne strains in China (Wang et al., 2012; Luo et al., 2017), and the L. monocytogenes $1 / 2 \mathrm{a}, 1 / 2 \mathrm{~b}, 1 / 2 \mathrm{c}, 3 \mathrm{a}$, and $4 \mathrm{~b}$ strains respectively belonged to ST87, ST3, ST5, ST8, and ST9 were found from the patients of listeriosis in China (Wang Y. et al., 2015). In this study, we found that $1 / 2 \mathrm{c}, 1 / 2 \mathrm{a}$ and $3 \mathrm{a}$ strains (including ST9, ST8 and PT4 as main types) existed in the raw pork. Moreover, environment and insects in the retail market were contaminated with high level by identical types L. monocytogenes strains, thus cross-transmission of L. monocytogenes among them would be an important risk factor of foodborne infection for human, considering the fact that pork is the most popular meat in China.
Insects could act as important mechanical vectors in the transmission of a variety of infectious diseases including foodborne infections (Ekdahl et al., 2005; Pava-Ripoll et al., 2015). But no knowledge about the insects as a vehicle of L. monocytogenes transmission was reported before in China. The L. monocytogenes isolation rate (20\%) from flies in this study was much higher than that of reported in the United States (PavaRipoll et al., 2015). Considering that flies and cockroaches were abundantly presented in the retail market, they could act as a mobile vehicle for spreading L. monocytogenes to every surface they contacted. Thus more effective strategies for insects control should be conducted to reduce the risk of L. monocytogenes contamination of raw pork in the retail market.

Repeated contamination of $L$. monocytogenes in a variety of food processing environments has been reported by various studies (Nucera et al., 2010; Ferreira et al., 2011; Williams et al., 2011; Pagadala et al., 2012; Vongkamjan et al., 2013; MuhteremUyar et al., 2015), but the information about it in the retail market was less studied. The study by Ferreira et al. (2011) showed that PFGE typing of 240 representative L. monocytogenes isolates offered evidence that these strains isolates from different production dates persisted for 10-32 months. In this study, 47 of 64 booths were found to be repeatedly contaminated mainly by persistent PT4 strains, which suggested that PT4 strains were more adapted to the environment. This observation not only supported that specific L. monocytogenes pulsotypes could persisted over time at a retail level but also suggested that these persistent L. monocytogenes contributed to repeated contamination of food, which was often consumed by people. A case of L. monocytogenes infection reported in 1989 due to consumption of turkey franks and 30 cases of L. monocytogenes in 11 US states caused by delicatessen turkey in 2000 were found had a close link on contamination sources via molecular subtyping, which indicated that outbreak strains may have persisted from the same source for 12 years and caused persistent food contamination (Wenger et al., 1990; Olsen et al., 2005). Besides, some researchers have found that environmental factors have been identified as key contributors to persistence 


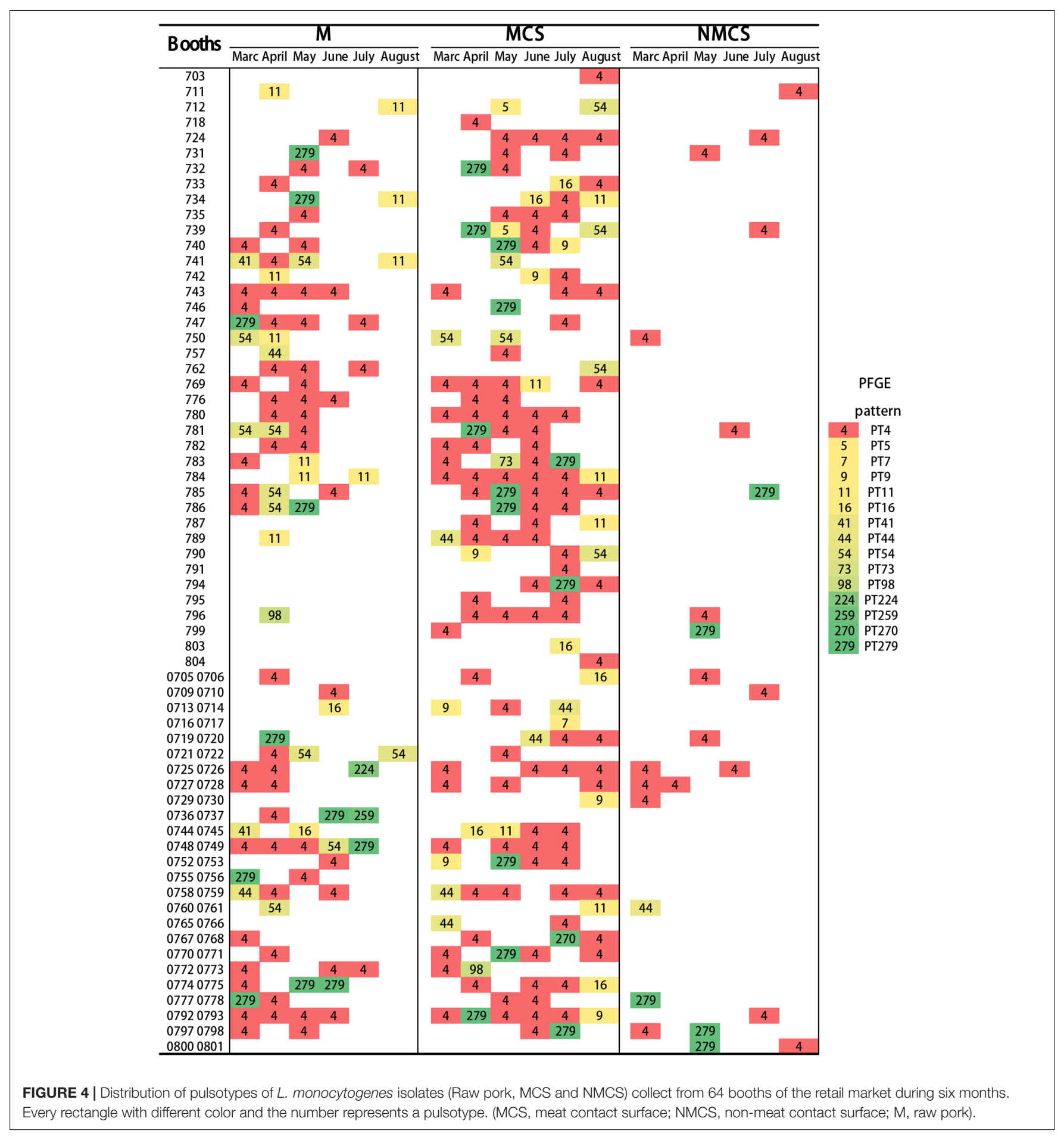

(Ferreira et al., 2014). These studies underscored environmental persistence leading to increased risk of human infections. In this study, we found the repeated contamination of L. monocytogenes in the environment especially in MCS (in particular the chopping boards and knives) was most serious, which would play the major role for L. monocytogenes transmission to the raw pork. Thus effective strategies such as cleaning and sanitizing would significantly reduce $L$. monocytogenes contamination of environment in the raw pork retail market, and then prevent the possible foodborne listeriosis in humans.

\section{CONCLUSION}

This study investigated the risk factors and level of L. monocytogenes contamination in raw pork retail markets in 
China. The results showed that $L$. monocytogenes contamination was higher in raw pork and MCS than in NMCS, insects in retail market had a high carriage of $L$. monocytogenes. Crosscontamination from MCS to raw pork acted as an important risk factor to transmit L. monocytogenes to raw pork. Insects were an important vector for L. monocytogenes transmission between environment and raw pork in the retail market. Specific and effective strategies to sanitize the environment and control insects are needed to reduce raw pork contamination in retail markets and the risk of human listeriosis.

\section{AUTHOR CONTRIBUTIONS}

HaL performed the major experiments, statistical analysis, and wrote the manuscript. PW did lots of work in experiments. LL helped in data analysis. XC, YiW, YaW, HiL, LZ, and SJ participated in sample collection. RL and CY helped in revising the paper. CY is the corresponding author. All authors approved the final manuscript.

\section{REFERENCES}

Ballesteros, L., Moreno, Y., Cuesta, G., Rodrigo, A., Tomás, D., Hernández, M., et al. (2011). Persistence of Listeria monocytogenes strains in a frozen vegetables processing plant determined by serotyping and REP-PCR. Int. J. Food Sci. Technol. 46, 1109-1112. doi: 10.1111/j.1365-2621.2011.02595.x

Barreiro, C., Albano, H., Silva, J., and Teixeira, P. (2013). Role of flies as vectors of foodborne pathogens in rural areas. ISRN Microbiol. 2013:718780. doi: 10.1155/ 2013/718780

Brown, L. G., Hoover, E. R., Ripley, D., Matis, B., Nicholas, D., Hedeen, N., et al. (2016). Retail deli slicer cleaning frequency-six selected sites, United States, 2012. MMWR Morb. Mortal. Wkly. Rep. 65, 306-310. doi: 10.15585/mmwr. $\mathrm{mm} 6512 \mathrm{a} 2$

Burall, L. S., Simpson, A. C., and Datta, A. R. (2011). Evaluation of a serotyping scheme using a combination of an antibody-based serogrouping method and a multiplex PCR assay for identifying the major serotypes of Listeria monocytogenes. J. Food Prot. 74, 403-409. doi: 10.4315/0362-028X.JFP-10-355

Chen, M., Wu, Q., Zhang, J., Wu, S., and Guo, W. (2015). Prevalence, enumeration, and pheno- and genotypic characteristics of Listeria monocytogenes isolated from raw foods in South China. Front. Microbiol. 6:1026. doi: 10.3389/fmicb. 2015.01026

Conficoni, D., Losasso, C., Cortini, E., Di Cesare, A., Cibin, V., Giaccone, V., et al. (2016). Resistance to biocides in Listeria monocytogenes collected in meatprocessing environments. Front. Microbiol. 7:1627. doi: 10.3389/fmicb.2016. 01627

Doumith, M., Buchrieser, C., Glaser, P., Jacquet, C., and Martin, P. (2004). Differentiation of the major Listeria monocytogenes serovars by multiplex PCR. J. Clin. Microbiol. 42, 3819-3822. doi: 10.1128/JCM.42.8.3819-3822.2004

Duffy, G., and Sheridan, J. J. (1997). The effect of temperature, $\mathrm{pH}$ and medium in a surface adhesion immunofluorescent technique for detection of Listeria monocytogenes. J. Appl. Microbiol. 83, 95-101. doi: 10.1111/j.1361-5072.1997. 00195.x

Ekdahl, K., Normann, B., and Andersson, Y. (2005). Could flies explain the elusive epidemiology of campylobacteriosis? BMC Infect. Dis. 5:11. doi: 10.1186/14712334-5-11

European Food Safety Authority (2011). The European Union summary report on trends and sources of zoonoses, zoonotic agents and food-borne outbreaks in 2009. Efsa J. 9:2090. doi: 10.2903/j.efsa.2011.2090

Ferreira, V., Barbosa, J., Stasiewicz, M., Vongkamjan, K., Moreno Switt, A., Hogg, T., et al. (2011). Diverse geno- and phenotypes of persistent Listeria monocytogenes isolates from fermented meat sausage production facilities

\section{FUNDING}

This work was supported by the Ministry of Science and Technology, People's Republic of China (Grant No. 2013ZX10004-101), State Key Laboratory of Infectious Disease Prevention and Control, China CDC (Grant No. 2015SKLID507), and National Institute for Communicable Disease Control and Prevention, China CDC (Grant No. 2016ZZKTB09).

\section{SUPPLEMENTARY MATERIAL}

The Supplementary Material for this article can be found online at: https://www.frontiersin.org/articles/10.3389/fmicb. 2018.01090/full\#supplementary-material

FIGURE S1 | The distribution of pulsotypes of $L$. monocytogenes isolates from repeated booths during 6 months. X-axis: six sampling months $Y$-axis: the number of repeated PTs. Different colors represent different pulsotypes of

L. monocytogenes isolates.

in Portugal. Appl. Environ. Microbiol. 77, 2701-2715. doi: 10.1128/aem.025 53-10

Ferreira, V., Wiedmann, M., Teixeira, P., and Stasiewicz, M. (2014). Listeria monocytogenes persistence in food-associated environments: epidemiology, strain characteristics, and implications for public health. J. Food Prot. 77, 150-170. doi: 10.4315/0362-028x.jfp-13-150

Fleming, D. W., Cochi, S. L., MacDonald, K. L., Brondum, J., Hayes, P. S., Plikaytis, B. D., et al. (1985). Pasteurized milk as a vehicle of infection in an outbreak of listeriosis. N. Engl. J. Med. 312, 404-407. doi: 10.1056/nejm 19850214312 0704

Forster, M., Sievert, K., Messler, S., Klimpel, S., and Pfeffer, K. (2009). Comprehensive study on the occurrence and distribution of pathogenic microorganisms carried by synanthropic flies caught at different rural locations in Germany. J. Med. Entomol. 46, 1164-1166. doi: 10.1603/033.046.0526

Freitag, N. E., Port, G. C., and Miner, M. D. (2009). Listeria monocytogenes from saprophyte to intracellular pathogen. Nat. Rev. Microbiol. 7, 623-628. doi: $10.1038 /$ nrmicro2171

Galvao, N. N., Chiarini, E., Destro, M. T., de Aguiar Ferreira, M., and Nero, L. A. (2012). PFGE characterisation and adhesion ability of Listeria monocytogenes isolates obtained from bovine carcasses and beef processing facilities. Meat Sci. 92, 635-643. doi: 10.1016/j.meatsci.2012.06.011

Gilmour, M. W., Graham, M., Van Domselaar, G., Tyler, S., Kent, H., TroutYakel, K. M., et al. (2010). High-throughput genome sequencing of two Listeria monocytogenes clinical isolates during a large foodborne outbreak. BMC Genomics 11:120. doi: 10.1186/1471-2164-11-120

Graves, L. M., and Swaminathan, B. (2001). PulseNet standardized protocol for subtyping Listeria monocytogenes by macrorestriction and pulsed-field gel electrophoresis. Int. J. Food Microbiol. 65, 55-62. doi: 10.1016/S0168-1605(00) 00501-8

Hoelzer, K., Sauders, B. D., Sanchez, M. D., Olsen, P. T., Pickett, M. M., Mangione, K. J., et al. (2011). Prevalence, distribution, and diversity of Listeria monocytogenes in retail environments, focusing on small establishments and establishments with a history of failed inspections. J. Food Prot. 74, 1083-1095. doi: 10.4315/0362-028x.jfp-10-567

Holt, P. S., Geden, C. J., Moore, R. W., and Gast, R. K. (2007). Isolation of Salmonella enterica serovar Enteritidis from houseflies (Musca domestica) found in rooms containing Salmonella serovar Enteritidis-challenged hens. Appl. Environ. Microbiol. 73, 6030-6035. doi: 10.1128/aem.00803-07

Huo, Z., Jun, X. U., and Gao, B. (2015). Investigation on the homology and antibiotic status of food-borne Listeria monocytogenes in Xicheng district of Beijing during 2012-2013. Chin. J. Health Lab. Technol. 25, 4143-4146. 
Inoue, S., Nakama, A., Arai, Y., Kokubo, Y., Maruyama, T., Saito, A., et al. (2000). Prevalence and contamination levels of Listeria monocytogenes in retail foods in Japan. Int. J. Food Microbiol. 59, 73-77. doi: 10.1016/S0168-1605(00)00 284-1

Jami, M., Ghanbari, M., Zunabovic, M., Domig, K. J., and Kneifel, W. (2014). Listeria monocytogenes in aquatic food products-a review. Compr. Rev. Food Sci. Food Saf. 13, 798-813. doi: 10.1111/1541-4337.1 2092

Kovacevic, J., McIntyre, L. F., Henderson, S. B., and Kosatsky, T. (2012). Occurrence and distribution of Listeria species in facilities producing ready-toeat foods in British Columbia, Canada. J. Food Prot. 75, 216-224. doi: 10.4315/ 0362-028x.jpp-11-300

Lamont, R. F., Sobel, J., Mazaki-Tovi, S., Kusanovic, J. P., Vaisbuch, E., Kim, S. K., et al. (2011). Listeriosis in human pregnancy: a systematic review. J. Perinat. Med. 39, 227-236. doi: 10.1515/JPM.2011.035

Liu, K., Wang, Y., Wang, T., He, C., Dai, H., Yu, B., et al. (2014). Investigation of Listeria monocytogenes in swine stool in an abattoir. China Anim. Health Inspection 31, 47-49.

Lopezvalladares, G., Tham, W., Parihar, V. S., Helmersson, S., Andersson, B., Ivarsson, S., et al. (2014). Human isolates of Listeria monocytogenes in Sweden during half a century (1958-2010). Epidemiol. Infect. 142, 2251-2260. doi: 10.1017/S0950268813003385

Lowe, D. E., Robbins, J. R., and Bakardjiev, A. I. (2018). Animal and human tissue models of vertical Listeria monocytogenes transmission and implications for other pregnancy-associated infections. Infect. Immun. 86, 801-817. doi: 10.1128/iai.00801-17

Luo, L., Zhang, Z., Wang, H., Wang, P., Lan, R., Deng, J., et al. (2017). A 12-month longitudinal study of Listeria monocytogenes contamination and persistence in pork retail markets in China. Food Control 76, 66-73. doi: 10.1016/j.foodcont. 2016.12.037

Miettinen, M. K., Björkroth, K. J., and Korkeala, H. J. (1999a). Characterization of Listeria monocytogenes from an ice cream plant by serotyping and pulsed-field gel electrophoresis. Int. J. Food Microbiol. 46, 187-192.

Miettinen, M. K., Siitonen, A., Heiskanen, P., Haajanen, H., Björkroth, K. J., and Korkeala, H. J. (1999b). Molecular epidemiology of an outbreak of febrile gastroenteritis caused by Listeria monocytogenes in cold-smoked rainbow trout. J. Clin. Microbiol. 37, 2358-2360.

Miya, S., Takahashi, H., Nakagawa, M., Kuda, T., Igimi, S., and Kimura, B. (2015). Genetic characteristics of Japanese clinical Listeria monocytogenes isolates. PLoS One 10:e0122902. doi: 10.1371/journal.pone.0122902

Montero, D., Bodero, M., Riveros, G., Lapierre, L., Gaggero, A., Vidal, R. M., et al. (2015). Molecular epidemiology and genetic diversity of Listeria monocytogenes isolates from a wide variety of ready-to-eat foods and their relationship to clinical strains from listeriosis outbreaks in Chile. Front. Microbiol. 6:384. doi: $10.3389 /$ fmicb. 2015.00384

Moosavy, M. H., Esmaeili, S., Mostafavi, E., and Bagheri Amiri, F. (2014). Isolation of Listeria monocytogenes from milks used for Iranian traditional cheese in Lighvan cheese factories. Ann. Agric. Environ. Med. 21, 728-729. doi: 10.5604/ 12321966.1129923

Muhterem-Uyar, M., Dalmasso, M., Bolocan, A. S., Hernandez, M., Kapetanakou, A. E., Kuchta, T., et al. (2015). Environmental sampling for Listeria monocytogenes control in food processing facilities reveals three contamination scenarios. Food Control 51, 94-107. doi: 10.1016/j.foodcont.2014. 10.042

Nucera, D., Lomonaco, S., Bianchi, D. M., Decastelli, L., Grassi, M. A., Bottero, M. T., et al. (2010). A five year surveillance report on PFGE types of Listeria monocytogenes isolated in Italy from food and food related environments. Int. J. Food Microbiol. 140, 271-276. doi: 10.1016/j.ijfoodmicro.2010. 04.016

O'Connor, L., O’Leary, M., Leonard, N., Godinho, M., O’Reilly, C., Coffey, L., et al. (2010). The characterization of Listeria spp. isolated from food products and the food-processing environment. Lett. Appl. Microbiol. 51, 490-498. doi: 10.1111/j.1472-765X.2010.02928.x

Olsen, A. R., and Hammack, T. S. (2000). Isolation of Salmonella spp. from the housefly, Musca domestica L., and the dump fly, Hydrotaea aenescens (Wiedemann) (Diptera: Muscidae), at caged-layer houses. J. Food Prot. 63, 958-960. doi: 10.4315/0362-028X-63.7.958
Olsen, S. J., Patrick, M., Hunter, S. B., Reddy, V., Kornstein, L., Mackenzie, W. R., et al. (2005). Multistate outbreak of Listeria monocytogenes infection linked to delicatessen turkey meat. Clin. Infect. Dis. 40, 962-967. doi: 10.1086/42 8575

Pagadala, S., Parveen, S., Rippen, T., Luchansky, J. B., Call, J. E., Tamplin, M. L., et al. (2012). Prevalence, characterization and sources of Listeria monocytogenes in blue crab (Callinectes sapidus) meat and blue crab processing plants. Food Microbiol. 31, 263-270. doi: 10.1016/j.fm.2012.03.015

Pagliano, P., Arslan, F., and Ascione, T. (2017). Epidemiology and treatment of the commonest form of listeriosis: meningitis and bacteraemia. Infez. Med. 25, 210-216.

Pan, Y. W., Breidt, F. Jr., and Gorski, L. (2010). Synergistic effects of sodium chloride, glucose, and temperature on biofilm formation by Listeria monocytogenes serotype $1 / 2 \mathrm{a}$ and $4 \mathrm{~b}$ strains. Appl. Environ. Microbiol. 76, 1433-1441. doi: 10.1128/AEM.02185-09

Pava-Ripoll, M., Pearson, R. E., Miller, A. K., and Ziobro, G. C. (2015). Detection of foodborne bacterial pathogens from individual filth flies. J. Vis. Exp. 96:e52372. doi: $10.3791 / 52372$

Ryu, J., Park, S. H., Yeom, Y. S., Shrivastav, A., Lee, S.-H., Kim, Y.-R., et al. (2013). Simultaneous detection of Listeria species isolated from meat processed foods using multiplex PCR. Food Control 32, 659-664. doi: 10.1016/j.foodcont.2013. 01.048

Sauders, B. D., Fortes, E. D., Morse, D. L., Dumas, N., Kiehlbauch, J. A., Schukken, Y., et al. (2003). Molecular subtyping to detect human listeriosis clusters. Emerg. Infect. Dis. 9, 672-680. doi: 10.3201/eid0906.020702

Self, J. L., Conrad, A., Stroika, S., Jackson, A., Burnworth, L., Beal, J., et al. (2016). Notes from the field: outbreak of listeriosis associated with consumption of packaged salad - United States and Canada, 2015-2016. MMWR Morb. Mortal. Wkly. Rep. 65, 879-881. doi: 10.15585/mmwr.mm6533a6

Simmons, C., Stasiewicz, M. J., Wright, E., Warchocki, S., Roof, S., Kause, J. R., et al. (2014). Listeria monocytogenes and Listeria spp. contamination patterns in retail delicatessen establishments in three U.S. States. J. Food Prot. 77, 1929-1939. doi: 10.4315/0362-028x.jfp-14-183

Sun, Z., Wu, X., Chen, R., Wang, L., and Dong, J. (2016). Previous cases of Listeria disease reported in China. Chin. J. Microecol. 28, 1323-1326. doi: 10.13381/j. cnki.cjm.201611023

Vongkamjan, K., Roof, S., Stasiewicz, M. J., and Wiedmann, M. (2013). Persistent Listeria monocytogenes subtypes isolated from a smoked fish processing facility included both phage susceptible and resistant isolates. Food Microbiol. 35, 38-48. doi: 10.1016/j.fm.2013.02.012

Wagner, M., and Stessl, B. (2014). Sampling the food processing environment: taking up the cudgel for preventive quality management in food processing environments. Methods Mol. Biol. 1157, 275-283. doi: 10.1007/978-1-49390703-8_23

Wang, K., Ye, K., Zhu, Y., Huang, Y., Wang, G., Wang, H., et al. (2015). Prevalence, antimicrobial resistance and genetic diversity of Listeria monocytogenes isolated from chilled pork in Nanjing, China. LWT Food Sci. Technol. 64, 905-910. doi: 10.1016/j.lwt.2015.06.015

Wang, W., Yan, S., Bai, L., Li, Z., Du, C., and Li, F. (2015). Quantitative detection on contamination of Listeria monocytogenes isolated from retail ready-to-eat meats in Beijing. J. Hyg. Res. 44, 918-921.

Wang, Y., Jiao, Y., Lan, R., Xu, X., Liu, G., Wang, X., et al. (2015). Characterization of Listeria monocytogenes isolated from human Listeriosis cases in China. Emerg. Microbes Infect. 4:e50. doi: 10.1038/emi.2015.50

Wang, Y., Zhao, A., Zhu, R., Lan, R., Jin, D., Cui, Z., et al. (2012). Genetic diversity and molecular typing of Listeria monocytogenes in China. BMC Microbiol. 12:119. doi: 10.1186/1471-2180-12-119

Wenger, J. D., Swaminathan, B., Hayes, P. S., Green, S. S., Pratt, M., Pinner, R. W., et al. (1990). Listeria monocytogenes contamination of turkey franks: evaluation of a production facility. J. Food Prot. 53, 1015-1019. doi: 10.4315/0362-028X53.12 .1015

Williams, S. K., Roof, S., Boyle, E. A., Burson, D., Thippareddi, H., Geornaras, I., et al. (2011). Molecular ecology of Listeria monocytogenes and other Listeria species in small and very small ready-to-eat meat processing plants. J. Food Prot. 74, 63-77. doi: 10.4315/0362-028x.jfp-10-097

Wu, L., Zhang, X. H., Chen, H., and Yin, X. L. (2008). Neonatal septicemia caused by Listeria monocytogenes: report of 6 cases. Zhonghua $\mathrm{Er} \mathrm{Ke} \mathrm{Za} \mathrm{Zhi} \mathrm{46,}$ 22-25. 
Wu, S., Wu, Q., Zhang, J., Chen, M., Yan, Z. A., and Hu, H. (2015). Listeria monocytogenes prevalence and characteristics in retail raw foods in China. PLoS One 10:e0136682. doi: 10.1371/journal.pone.0136682

Yang, X. J., Liu, G. H., Kong, X. Y., Huang, X., and Yang, H. (2008). Result analysis of food borne pathogens in food in Jilin Province during 2002 2007. Chin. J. Health Lab. Technol. 18, 1400-1402.

Zhang, C., Zhang, Y. F., Shen, X. Q., Zhong, Y., Bai, P. Q., and Ling-Fei, F. U. (2013). Analysis on monitoring data of pathogenic bacteria contamination in food from Pudong New Area of Shanghai City from 2006-2012. Occup. Health 29, 2801-2803.

Zhang, L. R., Tang, Y. Q., Zhen, B. J., and Zhang, C. (2007). Survey and study of contamination by Listeria monocytogenes and molecular epidemiological characteristic in 6 kind of foods in Tongzhou District. Chin. J. Health Lab. Technol. 17, 2306-2308. doi: 10.3969/j.issn.1004-8685.2007.1 2.074
Zhou, W. L., Zhu, M. L., Yan, C. Y., Lin, Z. L., and Liu, X. H. (2010). Neonatal sepsis caused by Listeria monocytogenes: case report of 7 cases. Zhongguo Dang Dai Er Ke Za Zhi 12, 154-155.

Conflict of Interest Statement: The authors declare that the research was conducted in the absence of any commercial or financial relationships that could be construed as a potential conflict of interest.

Copyright (c) 2018 Li, Wang, Lan, Luo, Cao, Wang, Wang, Li, Zhang, Ji and Ye. This is an open-access article distributed under the terms of the Creative Commons Attribution License (CC BY). The use, distribution or reproduction in other forums is permitted, provided the original author(s) and the copyright owner are credited and that the original publication in this journal is cited, in accordance with accepted academic practice. No use, distribution or reproduction is permitted which does not comply with these terms. 